\begin{tabular}{|c|c|}
\hline Title & $\begin{array}{l}\text { Local political dynamics of coastal and marine resource governance : A case study of tin-mining at a coastal community } \\
\text { in Indonesia }\end{array}$ \\
\hline Author(s) & Rosyida, Isma; Sasaoka, Masatoshi \\
\hline Citation & $\begin{array}{l}\text { Environmental development, 26, 12-22 } \\
\text { https://doi.org/10.1016/.envdev.2018.03.003 }\end{array}$ \\
\hline Issue Date & $2018-06$ \\
\hline Doc URL & http:/hdl.handle.net/2115/76954 \\
\hline Rights & $\begin{array}{l}\text { C2018, El sevier. Licensed under the Creative Commons A ttribution-NonCommercial-NoDerivatives } 4.0 \text { International } \\
\text { http://creativecommons.org/icenses/by-nc-nd/4.0/ }\end{array}$ \\
\hline Rights(URL) & http://creativecommons.org/icenses/by-nc-nd/4.0/ \\
\hline Tyре & article (author version) \\
\hline File Information & MANUSCRIPT FOR HUSCAP_Local political dynamics of coastal and marine resource governance.pdf \\
\hline
\end{tabular}

Instructions for use 


\title{
Local political dynamics of coastal and marine resource governance: A case study of tin-mining at a coastal community in Indonesia
}

\author{
Isma Rosyida , Masatoshi Sasaoka \\ Department of Human System Science, Graduate School of Letters, Hokkaido University, Kita 10, Nishi \\ 7, Kita-ku, Sapporo, Hokkaido 060-0808, Japan
}

\begin{abstract}
The purpose of this research was to explore the history of suction dredging and the local political dynamics of coastal resource governance in a village on Bangka Island, Indonesia. Using both qualitative and quantitative approaches, this study is significant for the quality of the data obtained through field visits, in-depth surveys, and interviews with the affected local community, representing different subsistence groups and socio-economic-political stratifications. This study found that both economic and local socio-political factors influenced the local community's acceptance of suction dredging. Compensation provided a compelling reason to agree to license mining activity. The key reasons for opposing suction dredging included resource depletion and deterioration, reduction in the quantity and price of fish, and difficulties associated with finding alternative livelihoods. Most of the net-fishing community disagreed with suction dredging, but the local political system stifled their opposition. The lack of fair decision-making processes for these licenses is indicative of an immature democracy.
\end{abstract}

\section{KEYWORDS:}

Tin-mining license; Suction dredging; Ecologically marginalized; Decision-making system; Indonesia

\section{Introduction}

One of the most highly mineralized countries in the world (O'Callaghan, 2010), Indonesia is also one of the world's largest tin producing countries (Aspinall and Eng, 2001), and relies heavily on its mining extractive industry (Spiegel, 2012). Tin sediments are widespread throughout Indonesia's western islands-including Bangka, Belitung, Singkep, and Karimun Kundur-which are regarded as 'The Indonesian Tin Islands' (Aleva et al., 1972). The most prominent of these islands are the Bangka Belitung Islands.

Indonesia first began mining tin in the 18th century, and this industry increased exponentially under the control of different countries (Aspinall and Eng, 2001). The sector's policies and regulatory frameworks have also undergone considerable change since 1998, largely due to Indonesian democratization, decentralization, and greater regional autonomy (Großmann et al., 2017). Indonesia embarked on its 'Big Bang' decentralization in the context of a significant economic and political transition in which the tin resource governance regime shifted from state-centred to regional-centred control of natural resource utilization (Spiegel, 2012), and regional-level governments assumed responsibility for issuing mining permits. Regulations and policies for sea mining activities include Decree No. 4 of 2009 (Mineral and Coal) (Mujiyanto and Tiess, 2013), Decree No. 27 of 2007 (Management of Small Islands and Coastal Resources) (Siry, 2011), and Decree No. 32 of 2009 
(Protection and Management of the Environment) (Campbell et al., 2012). Under these regulations, all tin mining companies are required to conduct environmental feasibility studies and Environmental Impact Assessments (EIAs), and license holders are obliged to pay royalties (Singawinata, 2006).

The importance of obtaining an EIA emerges along with growing evidence that numerous social and environmental issues are associated with the mining industry (Jenkins and Yakovleva, 2006) describes Japan's first major industrial pollution disaster as being Ashio's copper mining activity, which damaged farmlands and rivers. Bebbington and Williams (2008) found that increases in mineral extraction annually released over 13 billion $\mathrm{m} 3$ of effluents into Peru's watercourses, greatly affecting the availability and quality of water. Aspinal and Eng (2001) found that large-scale suction dredging in the Bangka Islands' coastal area was causing turbidity that would harm coral deposits and eventually lead to mass coral die-off. Manap and Voulvoulis (2015) found that suction dredging used for the underwater excavation of alluvial deposits is being conducted without proper mitigation and monitoring. These activities kill up to 30 per cent of the local coral reef within one year, through water contamination, coastal erosion, and noise. The damage caused in the sea, which is difficult to control because it is not visible, is not comparable to the damage that occurs on land. The Bangka Belitung University has reported that 18 out of 31 coral reefs were severely damaged by offshore tin-mining sediments from 2007 to 2011, and noted that the costs of recovering these reefs will greatly exceed the benefits that have already been derived (Ambalika, 2011).

Nevertheless, full legal compliance with state environmental regulations has proven insufficient for meeting the local community's expectations regarding mining issues (Prno and Slocombe, 2012). The EIA document - considered an environmental permit - does not guarantee that the mining activity will benefit a community. The voices of mining-affected communities, however, have become much more influential in mineral development decision-making processes. Weitzner (2010) highlights the human rights violations and abuses that occurred as the result of nickel-mining companies' operations in indigenous communities in Canada and Guatemala. Davis and Franks (2011) have noted many objections to the negative impacts associated with mineral extraction, which may lead to complete breakdowns of the local community approval with associated costs for the company, local communities, and the broader public. Spiegel (2012) found that numerous controversies in Bangka Island over tin mining governance occurred due to conflicts between companies and communities, and the resulting environmental and social problems associated with the revenues derived from their regions. These conflicts can fuel marginalized communities' grievances and poor management of their natural resources (Homer-Dixon, 2010). To some degree, Spiegel (2012) noted that livelihood insecurity and poor environmental governance resulted from the decentralization of governance to the local level, and the emergence of multiple new mining-related regulations that reformed the approval processes and locus of decisionmaking for mining permits.

Complexities associated with issuing mining permits cannot be separated from the power dynamic that links all stakeholders, including mining companies, governments, and the affected local community (Owen and Kemp, 2013). Prno and Slocombe (2012) commented that extractive industries must gain, and maintain, the approval of local communities in close geographic proximity to their operations, and particularly those that are most directly affected. Hall et al. (2015), however, found that it was challenging to meet the demands and interests of multilevel stakeholders involved in the licensing of mining operations. Thus, the local resource governance framework's decision-making process for issuing permits becomes problematic. The Bangka Island large-scale coastal suction dredging tin mining operations (hereafter CSDTMO) have negatively influenced the livelihoods of many people, and particularly fishers who rely heavily on coastal resources, and increased the likelihood of conflicts between fishers and the 
suction dredging company (KIARA, 2013). One source of conflict was the local authority's prioritization of mining development in the area, and violations of the mining licensing decision-making process at the local level. Therefore, decision-making processes for social mining permit issuance must be fully understood, to ensure sustainable and equitable access to local resources.

Previous studies provide thoughtful insights on tin resource governance, by focusing on land tin mining, and how it affects locals' livelihoods, and few field-based social studies have focused on resource governance decision-making processes for approving mining permits ( $\mathrm{Li}, 2002)$. Coastal mining activities pose greater threats to the coastal and marine ecosystem, and livelihoods that are highly dependent on the availability of these resources (Fanning et al., 2011). This study examines the factors that influenced local acceptance of suction dredging in a local coastal community in the Bangka Islands, and how this acceptance created a dilemma for then local fishers who were potentially impacted by this mining operation. It offers an in-depth understanding of local people's views on how and when suction dredging operations should be approved, or not, and how these views shape local decision-making processes for issuing mining permits.

This paper begins by considering the community's subsistence and resource utilization dynamics, and describes how suction dredging was introduced. Locals' attitudes to suction dredging operations are then discussed, before we conclude by considering the study's findings in regard to designing a fairer, and more socially just, local decision-making process for CSDTMO.

\section{Methods}

This study is based on a village on Central Bangka, Indonesia - under the pseudonym of Cape Villageformerly known as Bangka's clove-producing village. Cape Village is adjacent to the South China Sea coastline. Agriculture and plantations dominate the so-called upper village, while the so-called lower village is home to the fishing community. Cape Village has a land area of 859,654 ha, and is administered as three hamlets. The Malay ethnic group lives close to the agriculture and plantation area, while the Buton tend to live close to the sea (Fig. 1). subsistence groups. 


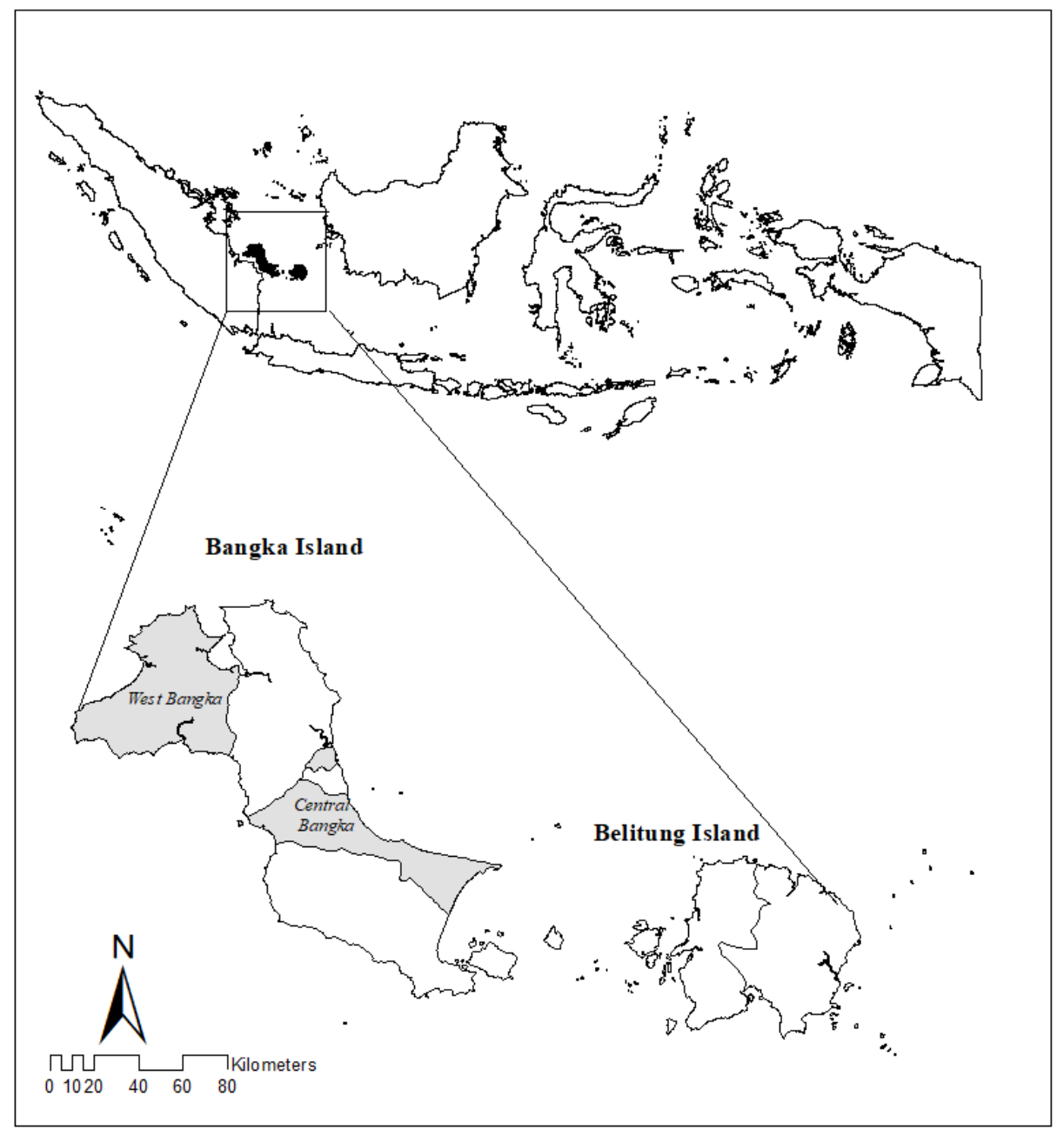

Fig. 1. Study map

The study's site selection considered local dependency on marine and coastal resources, and the community's previous level of acceptance of suction dredging operations. Household heads of some randomly selected households were interviewed using a cluster sampling technique. Seventy of 862 households were asked to participate in the survey, and many key informants were selected using the snowball sampling technique. This study used structured and semi-structured questionnaires to collect data in household surveys and key informant interviews. Field observations were used to clarify responses in the household surveys and key informant interviews. An extensive literature review of Internet-based journals, books, theses, and other documents was supplemented by a review of secondary documents from government and private institutions.

Households were grouped into six categories, based on their livelihood dependency: net fishers, Bubu fishers, seasonal fishers, miners, farmers, and others (shopkeepers, village officials, and labour involved in tin mining). Net fishers include those who earn the largest portion of their income from fishing using nets. Bubu fishers use fish traps, called Bubu, made of wire, while miners who are part of a group of small-scale community coastal miners use pontoon units for mining extraction, and seasonal fishers choose the work they will do by season. The smallest household group is comprised of farmers, 
due to the limited availability of suitable land for agriculture. Other categories include civil servants, shopkeepers, and the labourers who help small-scale tin miners. The data collected during key informant interviews were analysed qualitatively, and presented descriptively.

Our team obtained written research permits from Hokkaido University and the West Bangka District Government. The local village governments then granted our team verbal permission to conduct our research. Prior to the start of the research activities, we visited the study area to explain what we would be doing and why we were doing it; we later verbally asked the villagers for their agreement to those activities. We also asked the villagers to help us in identifying appropriate individuals (those who had relevant knowledge) for key informant interviews and focused group discussions. Prior to conducting each focused group discussion, key informant interview, and household survey, we re-explained to the participants the aim of the activity, how they were selected, that their comments would be recorded, and how we intended to use the data we collected. All participants were asked to give their verbal consent before we proceeded with and recorded the interviews. (Those who preferred not to be were not recorded.) We also collected personal and demographic information from participants. In our analysis, all data was kept anonymous to protect the respondents' confidentiality.

\section{Local subsistence and resource utilization dynamics}

The coastal community's subsistence activities are strongly influenced by weather and seasonal conditions, resource availability, and ownership. When the weather is good, fishing activities run smoothly; when the weather is poor, fishers' activities are hampered. Likewise, fishers have different kinds of catches, depending on the weather, different catch volumes, and 95 per cent of the fishers said they were now having more difficulties in predicting weather conditions.

Fishing tackle and boats are important assets in Cape Village. Most of the net fishers (87\%) are small scale fishers who use a traditional tackle with limited boat size and engine capacity. They fish a relatively small area, and catch fewer fish, as well as fewer types of fish, compared to Bubu fishers, who have a lot of fishing tackle, bigger boats, and machines. Fishers who need assistance, have to consult a Fish Collector, known as a Boss, either to get monetary help or to borrow boats and fishing instruments. This creates a social and economic patronage relationship between the boss and fishers. Most seasonal fishers (80\%) are less dependent on their boss than the net fishers, of which almost half depend on Fish Collectors. In addition, land is another resource needed for both commercial and daily fishers' subsistence. Most villagers who are net and seasonal fishers (77.14\%) do not have their own land; 87.5 per cent of the available land is used for agricultural purposes, and only 5.55 per cent of the total land is protected from tin-mining activity. Land ownership requires that they keep farming there, but the hilly land structure limits interest in agriculture, and capital shortages make them reluctant to own land.

A participatory survey of wealth showed that most net fishers have medium-low incomes, measured by five pre-identified wealth indicators: 1) housing type; 2) type of income; 3) amount of income; 4) debts; and 5). vehicle and home appliance ownership. Each indicator was scored from 1 to 5, according to a pre-identified local operational definition. All values were further calculated and ranked, before being categorized into three groups: 1) low: total score 5-11;2) medium: total score: $12-18$; 3) high: total score 19-25.

Facing seasonal uncertainties, climate change, depleted resources, and degradation of environmental quality caused by massive coastal mining development, people are being forced to manage their household incomes differently. About 60 per cent of the local community has multiple income sources, and how they adapt depends on their household assets, skills, potential income, and preferences. The greater the assets available and the higher the income earned by the head of the household, the lower 
the likelihood that the household will have multiple income sources. The more skills household members have, the greater is the likelihood they will have another income source. However, the low literacy rate63.3 per cent have not completed primary schooling — also affects their livelihood strategies.

Community members regard the sea as a communal resource that provides them with an array of social and economic benefits, to which they all have rights of access. The sea provides habitat for marine and coastal life, and has a reserve of the minerals from which tin is made. This mineral has been exploited by a state-owned enterprise under a government-issued license since the 1980s. Nonetheless, the escalation in mining by small-scale miners and large-scale enterprises coincides with the practice of other subsistence activities, and may have long-term negative ecological and social consequences. Such are the concerns of 86 per cent of the net and seasonal fishers, who, following the introduction of CSDTMO in neighbouring villages, are catching fewer fish. To date, suction dredging has had a significant impact on the number and variety of fish caught, and impacted fishers' incomes. As explained by SP, one of the net fishers (31-year-old male),

I used to get around $17.5 \mathrm{~kg}$ shrimp and fish, but now I get only get $2 \mathrm{~kg}$ of fish and $6 \mathrm{~kg}$ of shrimp per day, and sometimes I get nothing at all.

Another net fisher, MF (53-year-old male), made the following observation:

I used to catch 5-10 kg shrimps but no longer do because the mud has covered 30-40 $\mathrm{cm}$ depth on the floor. If the government does not stop the operations of suction dredging, then please put some borders in the sea so that the mud does not bother our fishing activity.

Therefore, local acceptance is mainly influenced by people's interests in the resources, how they will be impacted by suction dredging operations, and the benefits they will derive from suction dredging - including how local communities can develop a cooperative decision-making process for granting mining licenses to the suction dredging company (Fig. 2).

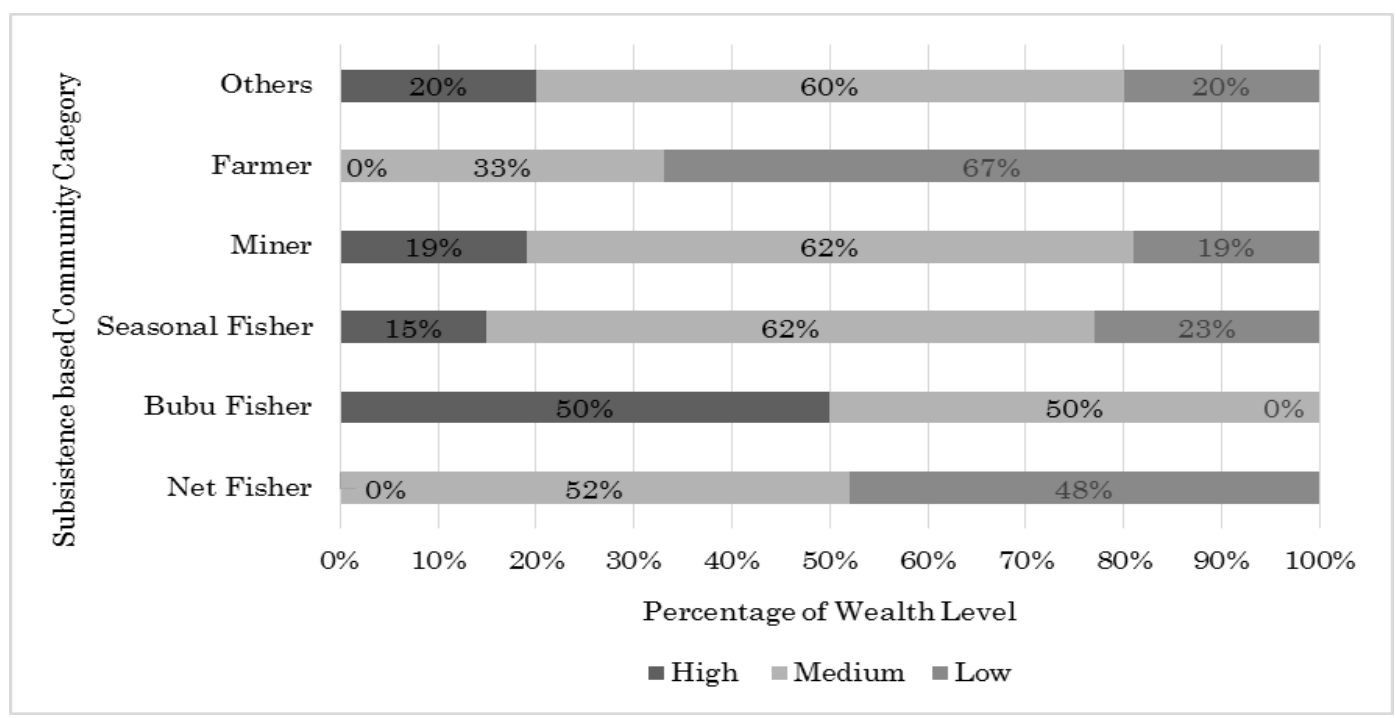

Fig. 2. Cape Village community member's incomes by occupations 


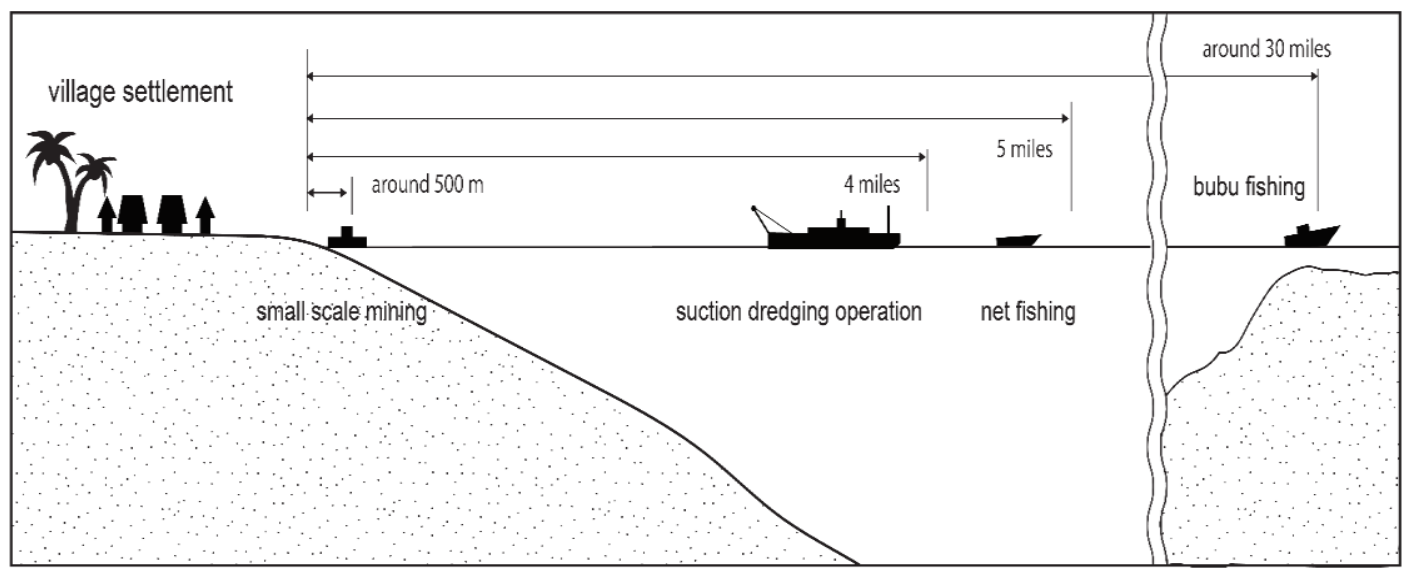

Fig. 3. Local resource utilization sketch

Fig. 3 depicts a community group's thoughts on creating separate working areas for each of the resource beneficiaries' village waters. Small-scale miners and fishers had conflicts because their workspaces overlapped, and both relied on marine and coastal life. To resolve their differences, they designated areas for small-scale mining operations and fishing grounds, and agreed that miners could only operate within $500 \mathrm{~m}$ of the shoreline, and fishing operations would be conducted between 0 and 5 miles from the shore.

Suction dredging creates a dilemma for the local community, whose members are competing for livelihoods, while facing possible shortages due to resource exploitation. The net fishing area may be impacted by suction dredging waste, such as wood chunks, kaolin soil, oil leaks, and mud, which causes sedimentation and covers coral reefs. RM (52-year-old male), a net Fisher, said the locals believe that mining waste is moved by the wind and wave flow, that it will pollute the sea, and ultimately affect their yields.

Suction dredging also limits when small-scale miners can use their resources, since suction dredging areas overlap with the small scale tin mining areas. Small-scale miners do not have legal permits, and so are threatened with expulsion. They may then be forced to find other mining grounds far from the village beach that will not disturb the fishing grounds. Bubu fishers' fishing grounds are relatively unaffected, because they are removed from the suction dredging mining ground.

\section{Decision-making process behind suction dredging}

Suction dredging was introduced to Cape Village gradually. Local communities maintain that they have inherited local knowledge of the natural resources available in the region, and that they have adapted this knowledge with new information about the importance of protecting the resources. As shown in Table 1, however, in 2014, outside parties (i.e. companies) expanded their businesses in Cape Village and the surrounding area, an area that is thought to have contained abundant tin resources. The community finally accepted the suction dredging company's proposal, with a number of conditions. 
Table 1. Historical summary of suction dredging penetration in Cape Village

Source: Key Informant Interviews, Household Survey 2014

\begin{tabular}{|c|c|}
\hline Year & Events \\
\hline 2009 & Suction dredging companies applied for exploration permit but were rejected \\
\hline 2010 & $\begin{array}{l}\text { January: Hundreds of The Cape Village community members, especially fishers, held a protest } \\
\text { against the suction dredging operation }\end{array}$ \\
\hline January & January to February: The Cape Village local community joined with neighboring villages' local \\
\hline 2014 & communities to engage in another protest against suction dredging \\
\hline June 2014 & Mid-2014: Cape Village backed accepting a submission for a suction dredging operating license \\
\hline August 2014 & $\begin{array}{l}\text { Village government parties drafted an agreement and got approval from the local community in } \\
\text { the form of signatures; more than two-thirds of the people who attended gave their agreement }\end{array}$ \\
\hline October & Suction dredging was planned to commence in Cape Village and surrounding villages in early \\
\hline 2014 & October \\
\hline
\end{tabular}

The community's internal decision-making process included several stages to consider each relevant party's negative and positive assessments. Two formal meetings were held to negotiate a mining permit for suction dredging operations. A public meeting finally decided to accept the company's presence, with several conditions. Fig. 4 provides a flowchart of the licensing procedure. Community approval is one pre-condition for requesting a mining license from the government. After the company creates a file with the village government, the company and representatives of the state-owned enterprise lobby the government, and apply for a permit to conduct a pre-assessment.

The local government then considers the company's application, and the company is required to conduct a pre-assessment-together with the village government-of the local community's circumstances, which is used to determine the type and level of compensation. The company offered the following forms of compensation: 1) cash, given to locals as initial allowances for fishers and miners directly affected by mining activities, and for rural development; 2) fishing boat flows (paths constructed to protect fishing boats when the waves swell; once the water recedes, fishers do not have to walk 500$1000 \mathrm{~m}$ to get to their boats); 3) land stripping, to peel a layer of soil from the bottom of the sea, to facilitate the process of soil suction that will help small-scale miners; and 4) suction dredger tailingsmining waste that still contains tin, which can be re-extracted-are given to the community to sell to the suction dredging company. 


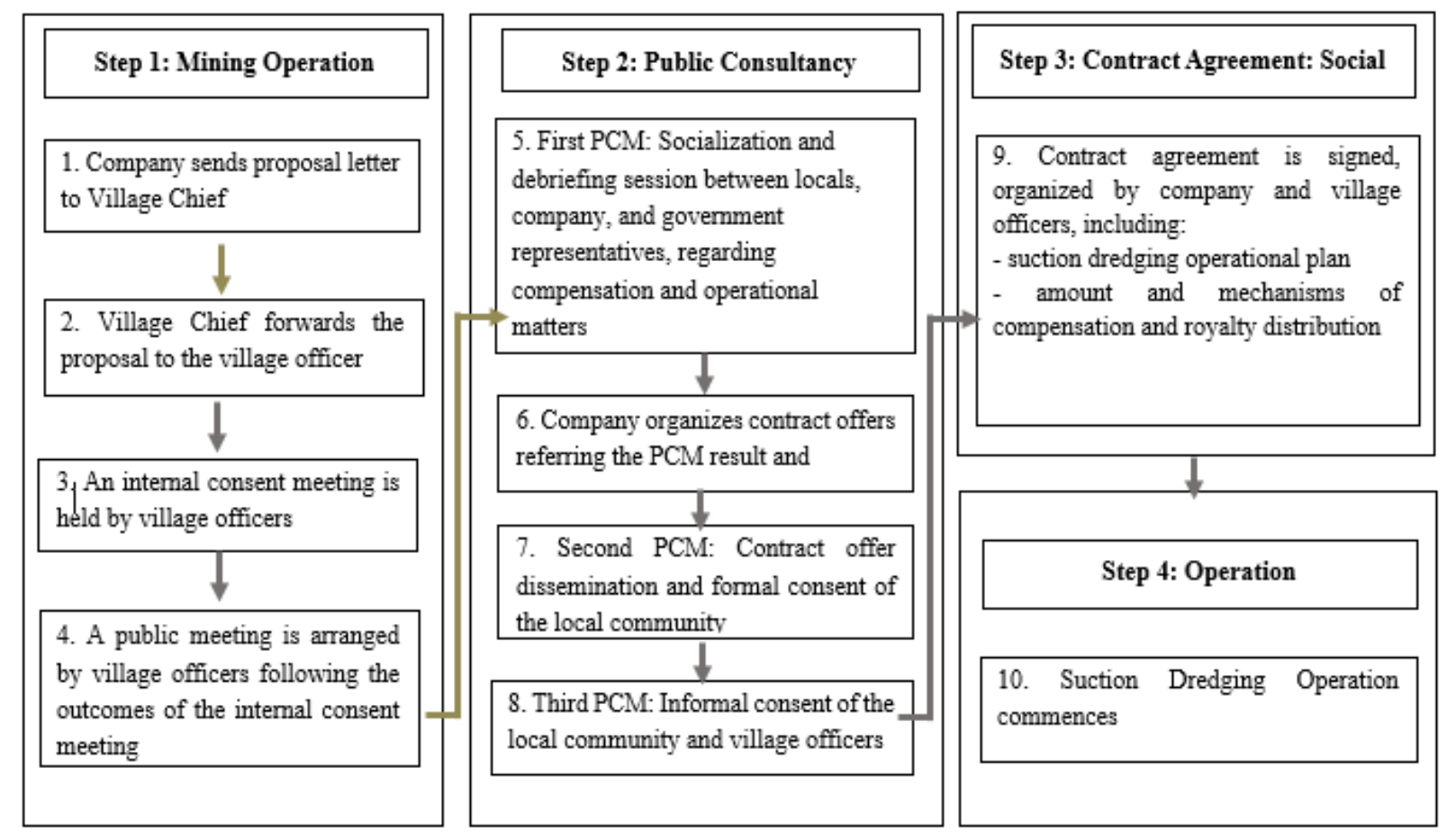

Fig.4. Flowchart of mining licensing procedure

The local government is then responsible for relaying information between external and internal stakeholders. The lobbying occurs in several stages, according to the amount of time allotted to discussions by the parties. Once community level agreement has been obtained, this information is communicated to the company and the regional and provincial levels of government. Suction dredging operations begin after all the parties have agreed to all the conditions. Prior to that, the community has given its final agreement to the social permit at another meeting. The local community's signatures are required to verify that it has approved the agreement, before the regional government will authorize a formal mining permit.

Fig. 5 depicts the relationships between all the parties that are supposed to be involved in the decision-making process. The local and regional governments bridge communications between the company and the community. Power relations internal to the decision-making process describe the local political situation in Cape Village. This process involves several stages, and includes each relevant party's negative and positive considerations. Community and local government representatives have several meetings in an effort to reach consensus. The local government accommodates meetings that involve various societal elements. Up to three meetings were held to negotiate the mining permit for suction dredging. From the first to the third public meeting, the net fishers' attendance declined from 64 to 26 per cent of the total net fishers. Meanwhile, Bubu fishers and miners' attendance was relatively stable at between 60 and 75 per cent. There was no significant change for farmers and other categories, who had a relatively low attendance (less than 10 per cent). At the first public meeting, less than 10 per cent of respondents who attended the public meeting gave their opinions. They preferred to listen to the information given by village officers and the company. During the second and third public meetings this number increased, but was still low, and less than 20 per cent were willing to talk. 


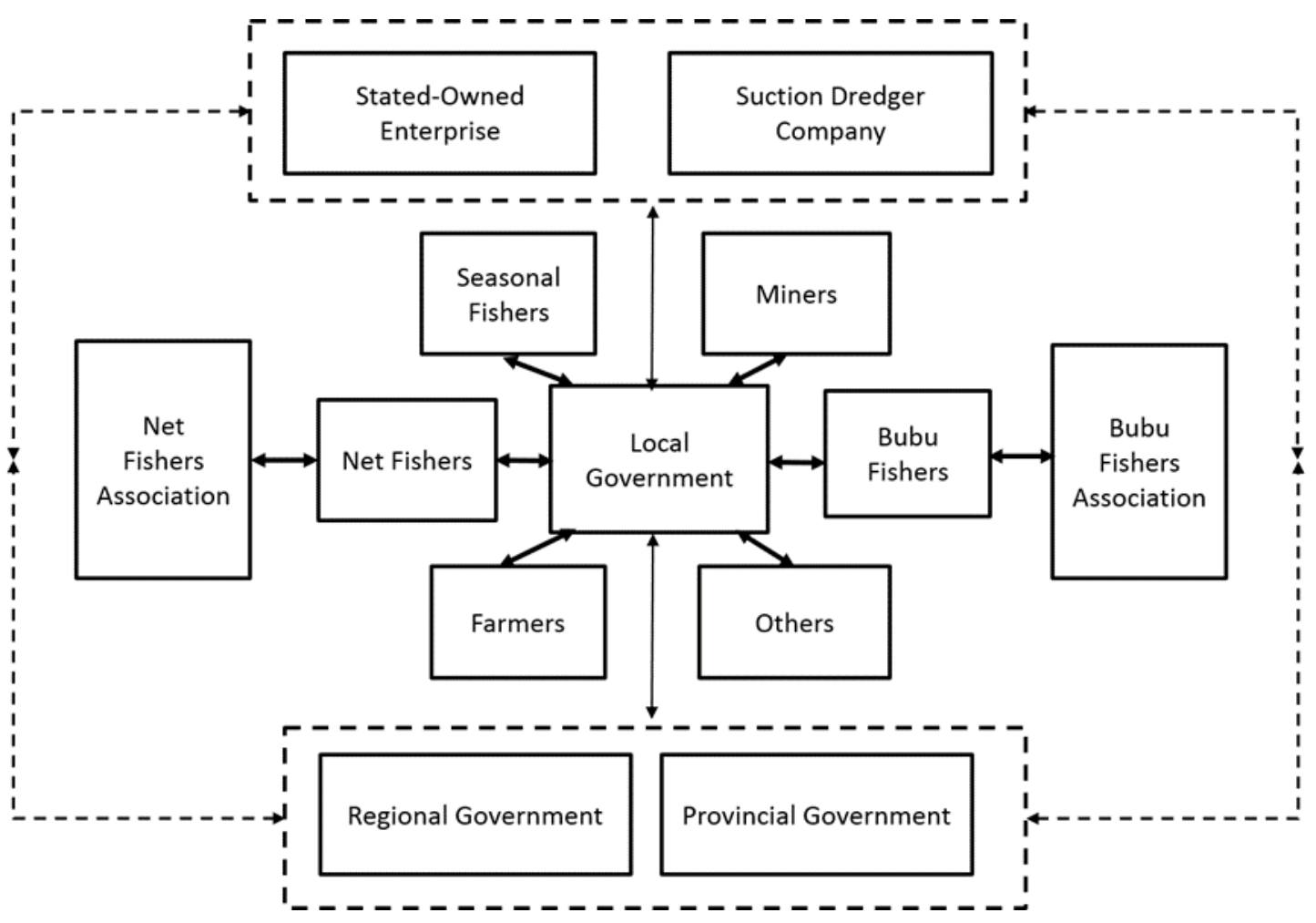

Fig.5 Stakeholders involved in mining license issuance.

\section{Attitude of local people towards suction dredging}

The application process requesting community approval was conducted in the local political arena, and involved multiple parties with different degrees of power and knowledge, until it finally entered the decision-making process. Nevertheless, locals offered different responses to suction dredging, as shown in Fig. 6.

Most of the locals, and especially Bubu fishers (80\%) agreed to allow suction dredging operations, while those who disagreed most were net fishers. Seasonal fishers and miners largely agreed (more than $60 \%$ ). Net fishers, in comparison, disagreed (40\%), with five of them objecting to possible future impacts, two to the imbalance in benefits and costs, and three who objected in consideration of their family and descendants' future. Bubu fishers were the smallest proportion (10\%) of the local community to disagree with suction dredging. The household survey also revealed that local farmers had a neutral attitude, because their economic activity is unrelated to suction dredging.

During the household survey, we found that three net fishers regretted their decision to agree to the suction dredging operation, but had agreed due to certain factors. KH (32-year-old male) said,

Because of the previous suction dredging, my income decreased by 75 per cent because it's getting so difficult to get fish. How can I agree after seeing this condition? When I visited the village office, the village chief told me that the suction dredging will go on with or without my agreement.

Another net fisher, SP (48-year-old male) said, 
Yes, I was also with him at that time. And the village government suggested me to agree because if I agree I would be compensated and if don't, I will not receive any compensation. Therefore, at that time, I thought to sign it, because they will operate even if I did not sign.

Even if they did not agree, these men were encouraged to approve it. Another net fisher, DD (44year-old male) said,

At first, I also thought to disagree, but because my friends had agreed, I decided to agree. Even if I had not agreed, I wouldn't have been able to do anything. I was worried that in the case of disagreement, something could happen to me.

This view explains the decision to agree, since his friends had agreed. In addition, there is a feeling of insecurity. However, some simply rejected the proposal in the beginning, and were not willing to sign. SD (43-year-old male) said,

The sea is my livelihood and source of income for the family. The income the sea gives me is the fortune that I have received from the Lord. My parents, who used to be fishers, always taught me to keep these principles. I would not willingly give my sea away, so let me stay with this rebel silent who cannot afford, but my little heart was crying, and I did not wish to approve it.

The minority did not express this attitude in public meetings, which should have provided a forum for them to express such views. SD prefers to shut his mouth and keep his distance from the supporting parties. One of the net fishers, UD (48-year-old male), in a preassessment in February 2014 said that he rejected the proposal due to the severity of the suction dredging operations, but when I met him in August 2015, he expressed a different opinion. He said,

I am aware that the suction operation is going to be a big threat to me and others, especially net fishers. But, personally, I am concerned about the long-term impact on our livelihood. After I reconsidered the economic benefits for our village, why do we not give them the opportunity to contribute to developing our village? Moreover, as I am a village office representative I should always support the government's positive plan. 


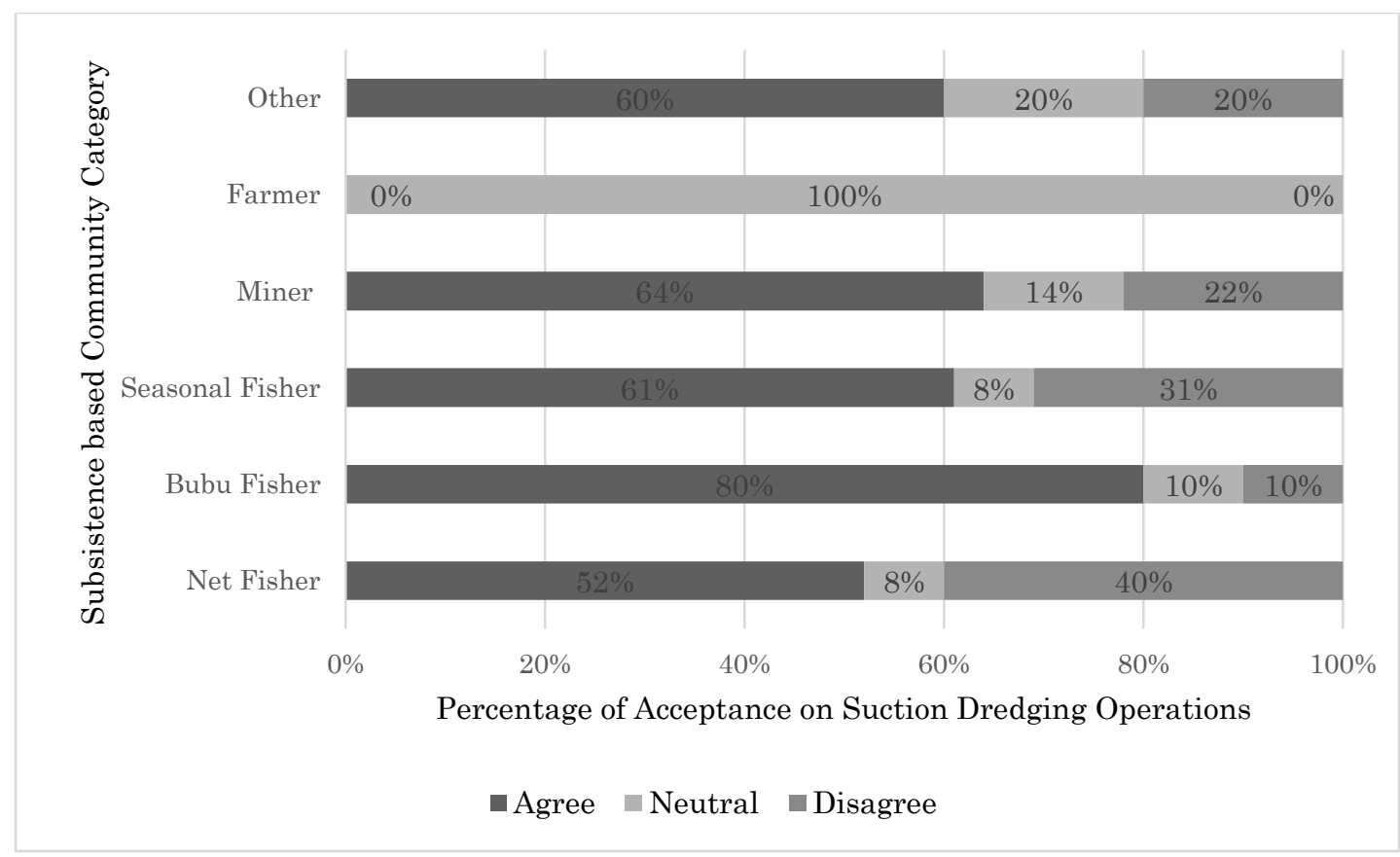

Fig.6. Community perspectives on suction dredging operation.

This statement reveals another reason the net fishers agreed. The Village Chief was functioning as a bridge between local community members and the suction dredging company. He had a personal influence on the people in his social circle. Local communities tend not to agree, but then they are not able to refuse, because of the personal burden it places on village officers. In the case of miners, of the nine miners who agreed to the suction dredging operation, five of them said they agreed because of the compensation provided, even though personally they were worried about the diminishing area available for their small-scale mining, while four other miners said they agreed because they were following the majority. Other miners who agreed tried to influence and convince those who disagreed.

Household surveys show that 72 per cent of the 18 net fishers who agreed with the suction dredging operation personally disagreed, but finally agreed; 46 per cent agreed because of the compensation; 38 per cent were influenced to support it by their relatives and bosses. Finally, 16 per cent agreed because they felt insecure. ZB (62-year-old male), a Bubu Fisher's Association representative who tended to be neutral when interviewed at his house, explained his support as follows:

The presence of a suction dredger will provide positive impacts for the Cape Village rural development, and Central Bangka District in general. I strongly agree and, as chief of the Fisher's Association, I have made efforts to socialize within my community group which urged fishermen to help provide support for this for the good of us all. Moreover, net fishers in general and other Bubu fishers are having the same trouble due to the huge and strong waves that hit our boats. If company will build a fishing boat flow for us, it means I can bring my boat to the village beach without any worries.

In a separate interview, $\mathrm{ZB}$ did not seem to reject suction dredging. For Bubu fishers, if suction dredgers do not interfere, it will not be a problem. This is similar to arguments by farmers and other local communities. Confirming the participation of certain stakeholders in decision making processes requires 
courage, to confirm and re-confirm, because different times and settings can influence their thinking, and so the decision-making process. Given their limitations, and realizing their inability to withstand the majority, net fishers who disagreed tended to remain silent, and not be confrontational.

Different groups have different attitudes towards the proposal, and its potential costs and benefits are a key factor. Forty per cent of net fishers consider new money one of the most important potential benefits, while only 16 per cent of them thought that suction dredger tailings would give them an alternative source of income. Fishers who considered potential benefits as being unimportant, assumed that these benefits were temporary, and observed that they needed marine resources for their future sustainability. DD (41- year-old male), a net fisher, said,

Compensation money is temporary. It's just a limited amount of money. Just imagine, after they finish their operations. How would I feed my family? What will my kids eat?

ZB (45-year-old male), one of the Bubu fishers, said Bubu fishers, and especially those who operate offshore, will not have a direct impact on suction dredging. Based on household surveys, 87 per cent of them believe that those benefits are very important; especially with regard to the fishing boat flow, which is important to them. This is not consistent with what the farmers said, because farming activities do not overlap with the suction dredging. Therefore, farmers tended not to get involved. As IB (56-yearold male), a farmer, said,

I just heard about the issue of compensation but I do not know anything and do not want to get involved. Moreover, I live here (Binjai), far from the mining location, so it's up to other people. I have no idea about that.

BD (49-year-old female), a shop owner, said,

If suction dredging operates in Cape Village, it will have a positive influence and our economy here will run more smoothly. This will affect the development of my business.

In general, suction dredging brings different multiplier effects to both the communities who are directly related to it and those who are not. Cape Village had several times been affected by suction dredging operations in the neighbouring villages. As observed by 78 per cent of the respondents, this affects the local community's economic activity, and particularly those who intersect directly with the suction dredging operating region. According to household interviews, the mining activity impacts that are significant to their economic activities include destruction of coral reef, mining waste (oil, mud, kaolin wood), limited small-scale mining grounds, and decreased fishing grounds.

Results of the household survey show that net fishers must bear the most severe impacts of mining activities, and more than 80 per cent of them considered the destruction of coral reefs, mining waste impacts, and decreasing fishing grounds to be the cost of suction dredging operations. Miners consider the impacts on their mining grounds, as did some Bubu fishers, who were part owners of minin units. Massive destruction of the coastal environmental may also have direct negative effects on the livelihoods of the adjacent population. Their biggest concerns are social conflicts, pollution, land degradation, and deforestation. Hence, mining activities inflict serious negative consequences on the lives of local communities, and the nation at large.

\section{Discussion}

The issuance of 'tin-mining licenses' in Cape Village was used to interpret how governance arrangements, and the environmental and social impacts of CSDTMO, are compelling those who really 
agree, those who disagree, and those who disagree, but have to agree, to speak with one voice and give their permission to conduct dredging operations. Local politics should ensure all stakeholders have equal influence in decision-making processes. Otherwise the process will negatively impact the minority that will feel their rights and obligations are being violated, and set the stage for future conflicts. The two main discussion points that will be addressed in this section are (1) factors that influence local acceptance of suction dredging, and (2) and how the absence of a mature democratic system influences local decision making on the issuance of mining permits.

\subsection{Factors influencing local acceptance of suction dredging}

The mining company knew that acquiring the social license was necessary to allow its operations to continue without community conflict (Prno and Slocombe, 2012). For locals, the granting of a social license often implies that they have been meaningfully involved in the decision making, and have received sufficient benefits (Prno, 2013). This discrepancy often leads to conflicts of interest when a mining company fails to meet societal expectations, particularly for the most vulnerable locals potentially impacted by mining operations (Hamann, 2003). Therefore, a key to mining permit issuance by communities is the belief that the social, environmental, and economic benefits of a project outweigh its potential impacts.

Suction dredging will potentially affect both the communities who are directly connected to it, and those who are indirectly connected to it. Both experience different levels of impact (positive or negative). Bubu fishers are regarded as the biggest beneficiaries, because they can receive all the benefits, including new money, or other compensation. Bubu fishers operate separately, 30 miles away from the village beach. Their distribution and storage of fish is conducted in the largest port in the provincial capital. Therefore, suction dredging will have no direct effect on their fishing activity, and they do not have to worry about the direct threat of resource depletion.

Net fishers, however, have to accept a resource depletion threat that will have a significant impact on their daily income, because they will catch fewer fish. The declining fish population will force them to extend the distance they have to travel to fish, and these distances are not compatible with the capacity of their boat engines, and their limited daily capital. ZT (a 58-year-old male) said that net fishers' operating costs are increasing due to increasing travel costs and time needed to fish, and they are experiencing up to 75 per cent reductions in their average incomes. Most fishers understand and recognize these threats. Asset ownership (such as land, vehicles, and other productive assets) and financial levels (including savings), will make it easier for them to find alternative livelihoods if their fishing income drops.

Miners will continue to have the same access to diverse employment opportunities, since most of them are at a productive young age and have good educational backgrounds. Thus, they might exchange their wage labour for other skilled jobs. Net fishers are older, have limited assets, and fewer skills, so they are less likely to find alternative livelihood sources. Bubu fishers can enjoy the benefits of permitting the suction dredging company to operate, without having to pay a high cost or sacrifice their own economic activities.

The suction dredging company and state-owned enterprise are the external bodies, while miners and fishers are the internal bodies who are dependent on the coastal and marine resources. Local and district governments are responsible for facilitating information-sharing between both of these bodies. Of all the categories, fishers (net, Bubu in particular, and seasonal fishers) and miners are considered as being the key stakeholders. Tables 2 and 3 show the driving and inhibiting factors in each community's categories. We exclude farmers and others, considering their neutral attitudes. Driving factors trigger acceptance of the suction dredging operations, while inhibiting factors are those that deter acceptance of 
these operations. If the economic driving factor is greater than the inhibiting factor, the community will tend to give consent to the suction dredging operation.

Monetary compensation was the reason the majority accepted the proposal. It pushed net fishers to agree on the mining permit. Both cash and tailing wastes are a source of additional income for them. Fishers in general, including net fishers, Bubu fishers, and seasonal fishers, are thought to have equal rights to compensation and revenues, while miners were focusing on a land stripping project. The suction dredging company offered respondents a variety of economic considerations in terms of compensation and revenue. Sociopolitical driving factors also influenced the local community's agreement or disagreement (Kuehnast et al., 2008). When an inhibiting factor is higher, the local community will tend to reject the operation. Practically, however, economic driving forces are not the only factor influencing the local community's decision making. Outside pressures were another reason for their acceptance. Other fishers' moral burden and insecure feelings also led them to accept the proposal.

Most members of the Cape Village community are hereditarily connected through family relationships. Social relationships and networks, based on kin, economic, political, and/or other types of 'personal' connections 'are the fabric of everyday life, facilitating day-to-day activities' (Sick, 2008).

Table 2

Economic factors that influenced the community's acceptance.

\begin{tabular}{|c|c|c|c|c|c|c|c|c|}
\hline \multirow[b]{2}{*}{ Factors } & \multicolumn{2}{|c|}{ Net Fisher } & \multicolumn{2}{|c|}{ Seasonal Fisher } & \multicolumn{2}{|c|}{ Bubu Fisher } & \multicolumn{2}{|c|}{ Miner } \\
\hline & $\begin{array}{l}\text { Driving } \\
\text { Factors }\end{array}$ & $\begin{array}{c}\text { Inhibiting } \\
\text { Factors } \\
\end{array}$ & $\begin{array}{l}\text { Driving } \\
\text { Factors }\end{array}$ & $\begin{array}{c}\text { Inhibiting } \\
\text { Factors }\end{array}$ & $\begin{array}{l}\text { Driving } \\
\text { Factors }\end{array}$ & $\begin{array}{c}\text { Inhibiting } \\
\text { Factors }\end{array}$ & $\begin{array}{l}\text { Driving } \\
\text { Factors }\end{array}$ & $\begin{array}{c}\text { Inhibiting } \\
\text { Factors }\end{array}$ \\
\hline Cash & + & & + & & + & & + & \\
\hline Boat Flow & + & & + & & + & & + & \\
\hline Mining Tailings & + & & + & & + & & + & \\
\hline $\begin{array}{l}\text { Stripped Land } \\
\text { Alternative }\end{array}$ & & + & & + & + & & + & \\
\hline $\begin{array}{l}\text { Livelihood } \\
\text { Sources }\end{array}$ & & + & & + & + & & & + \\
\hline $\begin{array}{l}\text { Resources } \\
\text { Depletion }\end{array}$ & & + & & + & + & & & + \\
\hline
\end{tabular}

Table 3

Social factors that influenced the community's acceptance.

Table 1 Social factors that influenced the community's acceptance

\begin{tabular}{|c|c|c|c|c|c|c|c|c|}
\hline \multirow{2}{*}{ Factors } & \multicolumn{2}{|r|}{ Net Fisher } & \multicolumn{2}{|c|}{ Seasonal Fisher } & \multicolumn{3}{|c|}{ Bubu Fisher } & Miner \\
\hline & $\begin{array}{l}\text { Driving } \\
\text { Factors }\end{array}$ & $\begin{array}{r}\text { Inhibiting } \\
\text { Factors }\end{array}$ & $\begin{array}{l}\text { Driving } \\
\text { Factors }\end{array}$ & $\begin{array}{r}\text { Inhibiting } \\
\text { Factors } \\
\end{array}$ & $\begin{array}{l}\text { Driving } \\
\text { Factors }\end{array}$ & $\begin{array}{r}\text { Inhibiting } \\
\text { Factors }\end{array}$ & $\begin{array}{l}\text { Driving } \\
\text { Factors }\end{array}$ & $\begin{array}{r}\text { Inhibiting } \\
\text { Factors } \\
\end{array}$ \\
\hline $\begin{array}{l}\text { Personal } \\
\text { Relationship } \\
\text { with Local }\end{array}$ & + & & + & & + & & + & \\
\hline $\begin{array}{l}\text { Flgure } \\
\text { Knowledge on } \\
\text { Suction }\end{array}$ & & + & & + & + & & & + \\
\hline
\end{tabular}




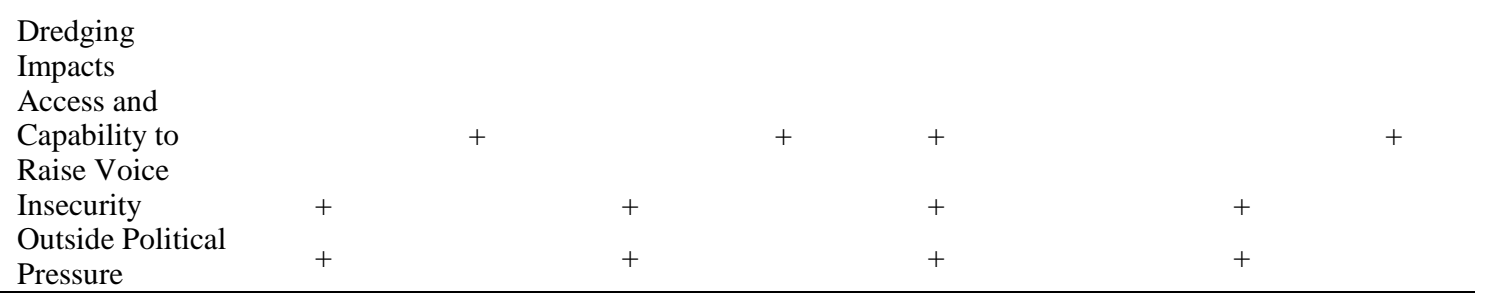

This impacts decision making indirectly, since when a relative or family member works as a village officer, other family members are reluctant to take decisions against them. HG (45-year-old) also mentioned that the Cape Village community has an Eastern culture that tends to avoid taking risks. Even though they understand and have sufficient knowledge of the impacts of suction dredging operations, they are not capable of expressing their disagreement, especially among net fishers. Even if a decision is contrary to their circle's majority opinion, they will tend to agree publically, though they do not personally agree. Their views on suction dredging reveal that political influence on progress is becoming one of the important factors to influence their decisions. This suggests that the written agreement confirming the local people's full agreement with the suction dredging operation is no guarantee that the stakeholders personally agree with it.

\subsection{Immature democratic process}

Obtaining a social license before conducting tin mining activity is inherent to a democratic system framework. To avoid conflicts of interest, a fair decision-making process should seriously consider both justice and equity in terms of all stakeholders. Agreement on revenues, the distribution of compensation, and the assignment of social and environmental responsibilities, should include all parties equally.

The local community was involved in the decision-making process through public meetings. As mentioned previously, only the attendance of net fishers declined. One of them was influenced by a village officer's invitation, which involved having a village officer give explicit instructions to hamlet chiefs who passed it on to a sub-hamlet chief. Thus, hamlet and sub-hamlet chiefs are thought to understand their community's alignment. One of three hamlet chiefs stated that he had been instructed by the village officer to limit the number of people invited, and tell sub-hamlet chiefs to prioritize the locals who would likely agree. Members of the local community who were likely to disagree were not prioritized in terms of invitations. Public meetings should allow all stakeholders to express their ideas, aspirations, and opinions freely. Limited opportunities and feelings of worry and lack of confidence were reasons for the low participation of attendees during public meetings.

Though, the local license was ultimately time- and context-specific, and thus reflected local social, economic, and environmental conditions, community priorities, capacities, and expectations will vary depending on the setting (Prno, 2013). Furthermore, mining companies can rarely point to a document that confirms that a license has been issued (Prno and Slocombe, 2012). However, from a democratic standpoint, decision making should involve all elements of society, and consider the potential impacts on all stakeholders. Thus, people such as net fishers, who will be more impacted by suction dredgeing activities, should be given special attention and genuinely involved in the decision-making process. Offshore mining activities, either by suction dredger or small miners in Cape Village waters, definitely 
affect the marine ecosystem, which is also a source of livelihood for locals. Thus, some parties will experience immediate direct and indirect impacts at both high and low levels. Therefore, all parties have equal rights to be involved in decision-making processes.

Cape Villagers were classified as those who could participate actively in the decision-making process, and those who were considered passive and preferred to follow the majority voice. The elite segment of the population, which included the village officer, and other beneficiaries, were taken into confidence because they shared the suction dredging mining company's interests. Meanwhile, the net fishers who were the ones most affected, faced a dilemma. Most of them were opposed to suction dredging because they knew it would greatly affect their economic activities in the present and the future. However, the local political system forced them to agree, and the influences exerted by other parties, and their own insecurity, further pressured them to accept the suction dredgers. As a result, they will have to sacrifice their rights of access and their control of natural resources, and find themselves further marginalized (Robbins, 2012).

Their agreement on suction dredging operations allows them to keep their motives hidden. Those who totally disagree with the operation cannot express their opinions, because of pressure exerted by other elite stakeholders, and their lack of confidence as minorities. Even if they cast their vote against the proposal, the licensing process will not be affected, because they are a minority. Thus, they are indifferent to expressing their opinion on suction dredging, and accept the operation to obtain compensation. The immature democratic process creates conditions that trigger this marginalization. Public involvement should act as a medium to accommodate all stakeholders' views, but the local level cannot accommodate their interests, because some local elites in effect have control over the decision-making process for mining permits. Immature democratic processes occur when decisions are made without fully consulting all stakeholders, or fully considering the whole village's views. The result is unsuccessful democratization that will possibly lead to a rebellion by unsatisfied stakeholders.

\section{Conclusions and research implications}

Net fishers who are ecologically marginalized are facing a paradoxical situation in which the majority disagrees with suction dredging, but the local political system forces them to accept it. This study found that economic and local sociopolitical factors influenced the acceptance of suction dredging by the local community. Compensation and alternative income sources were the compelling reasons that pressured the villagers to agree to issue mining licenses, while resource depletion and deterioration, reduction in fish prices, and difficulties finding alternative livelihoods were the key reasons for rejecting suction dredging. The absence of a fair decision-making system highlights the urgency of improving information disclosures by the government, locals, and companies, and thereby creating a forum in which decision makers can convey ideas and make fair decisions. To reach these goals, further research is needed to design decision-making processes that impartially consider positive and negative impacts, and consider proposals' strengths and weaknesses from each stakeholder's perspective.

Conflicts of interest

None.

\section{References}

Aleva, G.J.J., Bon, E.H., Nossin, J.J., Sluiter, W.J., 1972. A Contribution to the Geology of Part of the Indonesian Tin Belt: The Area Areas between Singkep and Bangka and around the Karimata Islands. Billiton. 
Ambalika, I., 2011. Dampak penambangan timah lepas pantai terhadap ekosistem terumbu karang di perairan rebo dan jeliti kecamatan sungailiat kabupaten Bangka provinsi kepulauan bangka Belitung. Universitas Bangka Belitung, Indonesia (Available). 〈http://ubb.ac.id/content/dampakpenambangan-timah-lepas-pantaiterhadap-ekosistem-terumbu-karang-di-perairan-rebo-dan $\rangle$.

Aspinall, C., Eng, P., 2001. Small-scale Mining in Indonesia. International Institute for Environment and Development, Mining Minerals, and Sustainable Development Report, 30.

Bebbington, A., Williams, M., 2008. Water and mining conflicts in Peru. Mt. Res. Dev. 28 (3), 190-195.

Campbell, S.J., Hoey, A.S., Maynard, J., Kartawijaya, T., Cinner, J., Graham, N.A., Baird, A.H., 2012. Weak compliance undermines the success of no-take zones in a large government-controlled marine protected Area. PLoS One 7 (11), e50074.

Davis, R., Franks, D.M., 2011.The costs of conflict with local communities in the extractive industry. In: Proceedings of the First Seminar on Social Responsibility in Mining.

Fanning, L., Mahon, R., McConney, P. (Eds.), 2011. Towards Marine Ecosystem-based Management in the Wider Caribbean 425 Amsterdam University Press, Amsterdam.

Großmann, K., Padmanabhan, M., von Braun, K., 2017. Contested development in Indonesia: rethinking ethnicity and gender in mining. Austrian J. South-East Asian Stud. 10 (1).

Hall, N., Lacey, J., Carr-Cornish, S., Dowd, A.M., 2015. Social license to operate: Understanding how a concept has been translated into practice in energy industries. J. Clean. Prod. 86, 301-310.

Hamann, R., 2003. Mining companies' role in sustainable development: the'why'and'how'of corporate social responsibility from a business perspective. Dev. S. Afr. 20 (2), 237-254.

Homer-Dixon, T.F., 2010. Environment, Scarcity, and Violence. Princeton University Press, New Jersey.

Jenkins, H., Yakovleva, N., 2006. Corporate social responsibility in the mining industry: exploring trends in social and environmental disclosure. J. Clean. Prod. 14 (3), 271-284.

KIARA (Koalisi Rakyat untuk Keadilan Perikanan), 2013. Nelayan Kepulauan Bangka Belitung Terus Diancam Tambang Timah. Press Release, November 14, 2013. Available online at 〈https://www.kiara.or.id/2112/〉 (Accessed on 26 April 2016).

Kuehnast, K., Dudwick, N., Clarke, M., O’Donnell, A., Rana, S., 2008. Whose Rules Rule. Everyday Border and Water Conflicts in Central Asia. The World Bank Group, Washington DC.

Li, T.M., 2002. Engaging simplifications: community-based resource management, market processes and state agendas in upland Southeast Asia. World Dev. 30 (2), 265-283.

Manap, N., Voulvoulis, N., 2015. Environmental management for dredging sediments-The requirement of developing nations. J. Environ. Manag. 147, 338-348.

Mujiyanto, S., Tiess, G., 2013. Secure energy supply in 2025: Indonesia's need for an energy policy strategy. Energy Policy 61, 31-41.

O'Callaghan, T., 2010. Patience is a virtue: problems of regulatory governance in the Indonesian mining sector. Resour. Policy 35 (3), 218-225. 
Owen, J.R., Kemp, D., 2013. Social licence and mining: A critical perspective. Resour. Policy 38 (1), 2935.

Prno, J., Slocombe, D.S., 2012. Exploring the origins of 'social license to operate'in the mining sector: perspectives from governance and sustainability theories. Resour.

Policy 37 (3), 346-357.

Prno, J., 2013. An analysis of factors leading to the establishment of a social license to operate in the mining industry. Resour. Policy 38 (4), 577-590 (667).

Robbins, P., 2012. Political Ecology: A Critical Introduction 16 John Wiley \& Sons, West Sussex.

Sick, D., 2008. Social contexts and consequences of institutional change in common-pool resource management. Soc. Nat. Resour. 21 (2), 94-105.

Singawinata, I.P., 2006. Decentralization and Local Development in Indonesia: A Case Study of Mining Transnational Corporation: 2-Doctoral Dissertation.

Siry, H.Y., 2011. In search of appropriate approaches to coastal zone management in Indonesia. Ocean Coast. Manag. 54 (6), 469-477.

Spiegel, S.J., 2012. Governance institutions, resource rights regimes, and the informal mining sector: regulatory complexities in Indonesia. World Dev. 40 (1), 189-205.

Weitzner, V., 2010. Indigenous participation in multipartite dialogues on extractives: what lessons can Canada and others share? Can. J. Dev. Stud./Rev. Can. d.études du Dév. 30 (1-2), 87-109. 